\title{
The Flow of River Water and Impurities Into The Black Sea
}

\author{
Timchenko VM* \\ Institute of Hydrobiology of the National Academy of Sciences of Ukraine, Ukraine
}

Submission: April 11, 2017; Published: July 16, 2018

Corresponding author: Timchenko VM, Institute of Hydrobiology of the National Academy of Sciences of Ukraine, Kyiv, Ukraine, Email: timchenkovm@gmail.com

\section{Short Communication}

The main inflow of river water into the Black Sea (up to $80 \%$ ) is concentrated in its northwestern part. Here, with the rivers Danube, Dnieper, Southern Bug and Dniester, an average of $250-260 \mathrm{~km}^{3}$ of water a year is received, which is one-third of the incoming part of the water balance of the sea. The greatest contribution to the total influx into the sea of river waters is made by the river. Danube. In modern conditions, an average of $205 \mathrm{~km}^{3}$ of water is received annually (up to a maximum of 313 , a minimum of $123 \mathrm{~km} /$ year) to the estuary area of this river. Despite the increase in the volume of irretrievable water consumption in the basin reaching about $10.6 \mathrm{~km}$ / year in recent years, modern methods of recording the flow of a noticeable tendency to decrease the water availability of the river against the background of its cyclical fluctuations have not yet been found (Hydrology of the Danube Delta, Moscow: GEOS, 2004). The Dniester, which flows into the same estuary, has a water content of more than $10 \mathrm{~km} /$ year. In some years, the annual runoff can be reduced to 4.5 or increased to $15.5 \mathrm{~km}^{3}$. In the change of low-water and high-water cycles of the Dniester, as well as all the rivers of the Black Sea, there is no strict pattern. After the commissioning of the Dubossary (1964) and Dniester (1984) reservoirs, the range of interannual and intra-annual flow fluctuations sharply decreased.

The average flow of the Dnieper in the estuary is $43.5 \mathrm{~km}^{3} /$ year, which is $15-18 \%$ lower than the natural rate. The annual volume of the river. The Southern Bug in natural conditions averages $3.39 \mathrm{~km}^{3}$, fluctuating in some years from 0.88 to $5.61 \mathrm{~km}$. Now, as a result of an increase in irrevocable water consumption, the river brings about $2.8 \mathrm{~km}$ of water to the Bug estuary per year. With water runoff, a large number of impurities enter the mouth areas of these rivers. The flow of suspended solids in the delta of the Dnieper is estimated at 0.8-1.2 million tons per year. The Danube River for the year discharges to the Black Sea an average of 42.9 million tons of suspended and 0.215 million tons of sediment. With the waters of the Southern Bug,
0.9 million tons of suspensions are taken out, and the Dniester is 1.4 million tons. Thus, the total solid runoff of the rivers of the North-Western Black Sea coast can roughly be estimated at 4647 million tons per year.

The predominant part of the suspended solids of the Danube (up to $80-90 \%$ ) reaches the sea. The solid flow of the Dnieper, the Dniester and the Southern Bug is substantially transformed in the same limans. One can speak of the predominant importance of the Danube for the Black Sea ecosystem in comparison with other major rivers. First of all, its role in eutrophication of the water area of the northwestern region of the Black Sea is great [1-3].

From what has been said, special attention is paid to the characteristics of the suspended substances contained in the Danube water. To them, above all, is turbidity. In the arms of the Kili Delta, according to the observations of the Danube Hydrometeorological Observatory, it is estimated at an average of $170 \mathrm{~g} / \mathrm{m}^{3}$, in the Kilia Arm $158 \mathrm{~g} / \mathrm{m}^{3}$, Staro-Istanbul 161, Prorva $172 \mathrm{~g} / \mathrm{mz}$. In general, the range of fluctuations in the turbidity of the water in the Danube delta is extremely wide - from several grams to $2-3 \mathrm{~kg} / \mathrm{m}^{3}$.

Within a year, the turbidity of the water in the estuary of the Danube is also changing significantly and is in some connection with the intra-annual distribution of river flow. In summer the turbidity is 2-3 times higher than in the rest of the year [4].

Particulate sediments of the Danube are dominated by particles of mineral origin. Their fractional composition is unstable. Usually up to $85-90 \%$ of suspensions are silty particles with a size of 0.005-0.15 mm. More or less large particles, i.e. sandy or clay, in the Danube water is low (up to 7-14\%). The high turbidity of the Danube water determines many aspects of river water quality. Thus, a large content of suspended mineral particles limits the development of phytoplankton, bacterioplankton and other planktonic organisms. Special 
studies (Oksiuk et al., 1990) made it possible to establish the feedback of phytoplankton indicators with the turbidity of water. The maximum development of phytoplankton is noted at a haze of up to $10-15 \mathrm{~g} / \mathrm{m}^{3}$. With an increase in the turbidity to $25-35 \mathrm{~g} /$ $\mathrm{m} 3$, the content of planktonic organisms in the water decreases to $40-50 \%$ of the maximum. The turbidity of water more than $80 \mathrm{~g} / \mathrm{m}^{3}$ prevents the abundant vegetation of phytoplankton: the number does not exceed 5-7 thousand $\mathrm{ml} / \mathrm{ml}$, biomass - about $5 \mathrm{mg} / \mathrm{l}$. With a suspended matter content of more than $180 \mathrm{~g} / \mathrm{m}^{3}$ in water, phytoplankton practically does not develop.

There is another aspect of the effect of suspended solids on water quality. It's about the ability to weigh suspensions of pollutants. Danube suspended sediments, for example, contain an overwhelming (up to $80-90 \%$ of the gross content) amount of substances such as heavy metals and organic compounds pesticides, petroleum products, phenols, synthetic surfactants, etc. In this case, the suspensions, on the one hand, act as a factor in the concentration of pollutants, on the other, as an indicator of the self-purification of the river.

Specialists of the Institute of Hydrobiology of the Academy of Sciences of Ukraine carried out a complex of studies, the results of which revealed a quantitative relationship between the suspended forms of manganese and copper and the composition of the suspended matter (Linnik, Timchenko, 1986). It is established that against the general background of significant variations in the content of the metals studied, the predominance of them in the composition of silty fractions (up to $70 \%$ of the ion mass) is observed for the seasons. The greatest amount of adsorbed manganese and copper is in the fraction of medium-grained particles $(0.015-0.05 \mathrm{~mm})$. Subsequent work of the authors showed that other metals are adsorbed in a large part on silty suspended particles.
The considerable regulation of the runoff of the Dnieper, Dniester and the Southern Bug rivers by reservoirs has led to the fact that not only the volume of their solid flow has sharply decreased, but also the composition of the suspended material that they bring to the sea has changed significantly. First of all, it is dominated by particles of organic origin (up to 70-90\%). The fractional composition of the mineral part of the suspended matter is mainly represented by clay particles, the dimensions of which do not exceed $0.005 \mathrm{~mm}$. The sedimentation of this material is very slow, therefore visually the streams of river water enriched with finely dispersed suspensions are usually seen in the sea at a great distance. Despite a good knowledge of the dynamics of the solid flow of these rivers, the assessment of the volume and mode of receipt of suspended material directly into the sea (after the transit of river water through estuaries) is a task not completely solved. We are talking about the need for a very thorough study of the processes of physico-chemical and biological transformation of suspended forms of pollution. The latter, as noted, are the rivers of the North-Western Black Sea that predominate in the water.

\section{References}

1. Oksiuk OP, Ivanov AI, Karpezo Yu, I Timchenko VM (1990) Dependence of quantitative indices of phytoplankton on the concentration of suspended matter in the Danube. Hydrobiol Zhurnal 26(N3): 42-47.

2. Linnik PN, Timchenko VM (1986) On the content of heavy metals on the suspended Danube water. Gidrobiol Zhurnal 22(N3): 76-79.

3. Zaitsev Yu P, Garkavaya GP, Nesterova DA, Polischuk LN (1989) The Danube is the main source of eutrophication of the Black Sea. Hydrobiol Zhurnal 25(N4): 21-23.

4. (2004) Hydrology of the Danube Delta. GEOS, Moscow, Russia, p. 448.

\section{Your next submission with Juniper Publishers will reach you the below assets}

- Quality Editorial service

- Swift Peer Review

- Reprints availability

- E-prints Service

- Manuscript Podcast for convenient understanding

- Global attainment for your research

- Manuscript accessibility in different formats

( Pdf, E-pub, Full Text, Audio)

- Unceasing customer service

Track the below URL for one-step submission https://juniperpublishers.com/online-submission.php 